\title{
Private Counsel and the Proposed Reforms of Investor-State Dispute Settlement (ISDS)
}

\author{
Jonathan R. Kabre* and Andreas R. Ziegler ${ }^{+}$
}

\begin{abstract}
This chapter examines the impact that ISDS reforms will have on counsel's activities. More specifically, it discusses two specific amendments namely the establishment of an Advisory Centre on Investment Law (ACIL) and the elaboration of a code of conduct -using the example of the CETA. On one hand, this chapter tries to demonstrate that counsel may benefit from the establishment of the ACIL notably because it will help them to refocus on assisting litigant states and not representing them. Admittedly, this Advisory Centre may provide legal services to litigant parties in the same fashion counsel do. But, and given the number and the length of investment disputes, such a centre cannot be entrusted with the exclusive management of all those disputes. Rather, we advocate in favour of complementary between them as it has occurred for the World Trade Organization (WTO) with the Advisory Centre of WTO Law (ACWL) and the roster of counsel.
\end{abstract}

On the other hand, most recent investment agreements have tackled the issue of ethics with the inclusion of provisions regulating the double-hatting and the adoption of a code of ethics for arbitrators. Even if these amendments are primarily directed towards arbitrators, they may be indirectly applicable to counsel in some cases as it will be discussed. We will conclude with some recommendations regarding the negotiations currently going on at UNCITRAL.

\section{Keywords}

\footnotetext{
* Ph.D. in International Law

Center of Comparative, International and European Law, University of Lausanne (Switzerland)

rkabre@unil.ch

+ Professor of Law

Center of Comparative, International and European Law, University of Lausanne (Switzerland)

andreas.ziegler@unil.ch
} 
Counsel; Law Firms; Advisory Centre; Counsel Fees; Double-hatting; Ethics; Code of Conduct; Private Actors, International Investment Law. 


\section{Chapter's Index}

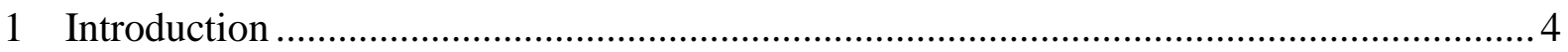

2 Private Counsel and the ACIL: complementary or competition? .................................... 5

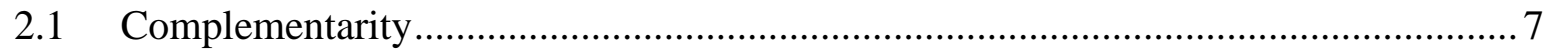

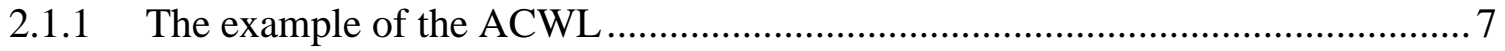

2.1.2 The workload in ISDS is too heavy to be exclusively handled by an ACIL ....... 8

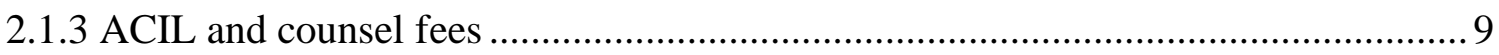

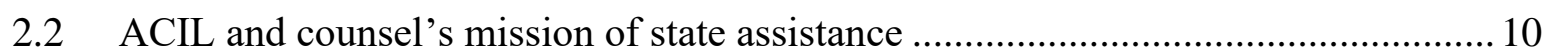

2.2.1 Representation and assistance before international courts and tribunals ............ 10

2.2.2 Problems arising regarding the appointment of (external) counsel ..................... 11

2.2.3 Some benefits counsel may gain from the establishment of an ACIL ................ 15

3 Counsel under the Comprehensive Economic and Trade Agreement............................. 15

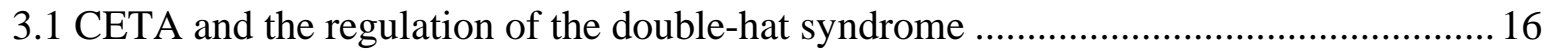

3.2 A binding code of conduct for arbitrators (and counsel)? ..................................... 18

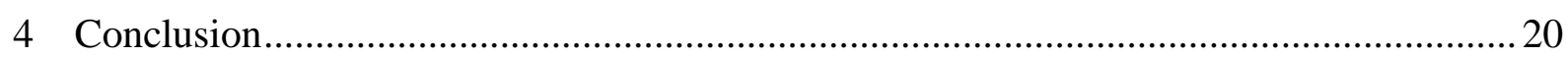


Investor-State Dispute Settlement (ISDS) is currently going through a wide process of reforms that is taking place both at multilateral and at bilateral level. On the multilateral side, the United Nations Commission on International Trade and Law (UNCITRAL) has entrusted its Working Group III with a mandate to work on the possible reform of ISDS. More specifically, the mandate given to this group in 2017 is threefold: first, to identify and consider concerns regarding ISDS; second, to consider whether reform is desirable in light of any identified concerns; and third, if reform is desirable, to develop any relevant solutions to be recommended to the Commission. ${ }^{1}$

In this sense also, the International Center for the Settlement of Investment Disputes (ICSID) launched the current amendment process in October 2016 with an invitation to states and the public to suggest topics that merit consideration and amendments. After extensive rounds of consultations with Member states and the public, the ICSID Secretariat published its third working paper on proposals for rule amendments on 16 August $2019 .^{2}$

At the bilateral level, some of the recent Bilateral Investment Treaties (BITs) concluded by states like Brazil, India or the European Union contain innovative aspects and provisions that can be viewed as reforms to the current system of ISDS. In this way, Brazil's recent BITs, labelled Cooperation and Investment Facilitation Agreements (CIFAs), do not contain ISDS but, rather establish a system combining dispute prevention mechanisms with the creation of institutions to ensure continued communication and foster cooperation, and state-to-state arbitration. ${ }^{3}$ On the other side of the spectrum, the Comprehensive Economic and Trade Agreement (CETA) concluded between the European Union and Canada establishes a Multilateral Investment Court.

These reforms are the response to criticism and concerns voiced against ISDS for several years. The dissatisfaction with the current ISDS regime falls within two broad categories: on one

\footnotetext{
${ }^{1}$ UNCITRAL, Report of Working Group III (Investor-State Dispute Settlement Reform) on the work of its thirtyfourth session (Vienna, 27 November-1 December 2017), https://undocs.org/en/A/CN.9/930/Rev.1 (last accessed 13 January 2020), p. 3.

2 ICSID, Proposals for Amendment of the ICSID Rules - Working Paper \# 3, August 2019, https://icsid.worldbank.org/en/Documents/WP 3 VOLUME_1_ENGLISH.pdf (last accessed 13 January 2020), p. 1. The paper builds on the proposals that were originally published in August 2018 (Working Paper \# 1) and March 2019 (Working Paper \# 2).

${ }^{3}$ Vidigal and Stevens (2018), pp. 475-512.
} 
hand, the processes and outcomes of ISDS are criticized because of the cost and the length of the proceedings. Also, the lack of consistency, coherence, predictability and correctness of arbitral decisions has been underlined. On the other hand, arbitrators and decision-makers are accused of lacking independence and impartiality.

Our chapter proposes to analyse some of these reforms from the perspective of the role of the counsel. Prima facie, the roles of counsel ${ }^{4}$ appear to have been forgotten in these reforms even though they are playing an irreplaceable role in ISDS. However, we think that these reforms will necessarily have an impact on counsel's activities in the context of ISDS and this chapter aims at assessing such an impact. The question is not whether, but rather to what extent, counsel will be affected by the possible reforms of ISDS. It may seem premature to analyse these amendments as some of them are still being discussed. However, we think it is worth reflecting upon these reforms since some of them have already been put forward and discussed by academics. These innovations are contained in recent investment agreements or have been included in the agenda of intergovernmental organisations such as ICSID or UNCITRAL. Rather than a comprehensive study of all these reforms, the scope of our chapter will be limited to two reforms ${ }^{5}$ : First, the impact of the establishment of an Advisory Centre on Investment Law (ACIL) on counsel's activities will be examined (2). This option has been proposed as a reform to the issue of costs and duration of ISDS. Second, the recent provisions of the CETA concerning the ethics of decisions-makers (the code of conduct) will be studied mainly to see how they can be applied to counsel. This seems particularly relevant in relation to the independence and impartiality of arbitrators and decision makers in International investment law, and more specifically ISDS (3).

\section{Private Counsel and the ACIL: complementary or competition?}

\footnotetext{
${ }^{4} \mathrm{We}$ use the term (private) counsel here for individuals and companies that provide (legal) advice and represent parties to disputes; normally these will be law firms and their staff. They can also be (former) academics or civil servants who are normally paid for their services and act in their private capacity.

5 The reforms we propose to examine are included in the "five initial reform topics identified in the New York session in April 2019', see UNCITRAL, Report of Working Group III (Investor-State Dispute Settlement Reform) on the work of its thirty-seventh session (New York, 1-5 April 2019), https://undocs.org/en/A/CN.9/970 (last accessed 13 January 2020), p. 15, para. 84.
} 
It is often criticized that ISDS is very expensive (even if some national litigation can also be rather expensive). ${ }^{6}$ The cost involved in ISDS includes tribunal costs and parties' costs. ${ }^{7}$ The big portion of these costs ( 80 to $90 \%$ and, perhaps, more) is normally comprised of parties' legal costs, that is, lawyers and experts' fees as well as costs incurred for the witnesses. On average, claimant's legal costs are around 6 millions USD and the respondent's legal costs are around 5 millions USD. ${ }^{8}$

To reduce these costs, many options are envisaged from the promotion of dispute settlement mechanisms other than arbitration to the replacement of ad hoc arbitrators by full-time judges, third party funding or the establishment of an advisory centre. It is striking to note that while they cover a big portion of ISDS' costs, very few options actually deal with counsel fees. Among the options proposed and discussed, the establishment of an ACIL may have an impact on counsel's activities. The goal of such an advisory centre is to " support developing countries and SMEs [small and medium enterprises] in ISDS" by providing them with "legal services and capacity-building programmes on ISDS'. This idea is not new and has been already discussed extensively in the literature. ${ }^{9}$ This option is on the UNCITRAL provisional agenda. ${ }^{10}$ Recently, the European Union (EU) has envisioned associating an advisory centre to its Multilateral Investment Court (MIC). ${ }^{11}$ Also, the Columbia Center for Sustainable Investment (CCSI), on behalf of the Ministry of Foreign Affairs of the Netherlands, is preparing a scoping study on securing adequate legal defence in proceedings under international investment agreements and is examining the opportunities and challenges presented by a number of proposed institutional solutions, including but not limited to the establishment of an Advisory Centre on International Investment Law (ACIL).

The first and unique advisory centre in international law was established in the context of the WTO in 2001:the Advisory Centre on WTO Law (ACWL). Since this centre has been

\footnotetext{
${ }^{6}$ UNCITRAL, Report of Working Group III (Investor-State Dispute Settlement Reform) on the work of its thirtyfourth session (Vienna, 27 November-1 December 2017), https://undocs.org/en/A/CN.9/930/Rev.1, (last accessed 13 January 2020), p. 7.

${ }^{7}$ One author speaks about "parties own legal costs and tribunal and institutional administrative expenses for conducting the arbitration", Franck (2019), p. 135.

${ }^{8}$ Langford, Behn and Létourneau-Tremblay (2019), p. 7.

${ }^{9}$ See, for example, Gottwald (2007), pp. 237-275; Sauvant and Ortino (2013), pp. 119-122; Joubin-Bret (2015), pp. 1-13; Alisher (2016), pp. 1-3; Schwieder (2018a), pp. 628-666; Schwieder (2018b), pp. 1-3; Sharpe (2019), pp. 1-4; Sauvant (2019), pp. 1-17.

${ }^{10}$ See UNCITRAL Working Group III (Investor-State Dispute Settlement Reform), Possible Reform of InvestorState Dispute Settlement (ISDS) Advisory Centre, Note by the Secretariat, https://undocs.org/en/A/CN.9/WG.III/WP.166 (last accessed 14 January 2020), pp. 5-6.

${ }^{11}$ Brown (2017), pp. 689-690.
} 
successful, the idea of transposing its concept into the context of ISDS has been envisaged and tested. American and Asian countries also tried to establish such a centre but all their efforts were not crowned with success. ${ }^{12}$ Some authors analysed the barriers to be overcome for using this example (ACWL) in $\operatorname{ISDS}^{13}$ or the missions this centre must be entrusted with. ${ }^{14}$ Less discussed, however, is the potential impact of such a centre on the activities of counsel since both of them will provide legal services to litigant state parties. Some authors suggest that lobbying by private law firms might have discouraged initiatives for the establishment of an ACIL at regional level (Latin America and ASEAN regions). This lobbying may be perceived as a sign of a possible antagonism. ${ }^{15}$ Another possible sign of antagonism is to found in the submissions to the Working Group where some states think that this centre should act "as counsel when there is a dispute." 16 These signs raise the question of the kind of relationship that might exist between an advisory centre and counsel: complementary or competition? We think that it is necessarily complementarity that should exist between them (2.1) and that the ACIL will help counsel to refocus on their mission of assisting states (2.2).

\subsection{Complementarity}

The reasons for this complementarity (and the rejection of competition) are to be found at three levels: Firstly, the ACWL has worked in collaboration with counsel and law firms (2.1.1). Secondly, the workload in the field of ISDS is too heavy to be handled only by an ACIL (2.1.2). Thirdly, the ACIL will have a limited impact on counsel fees (2.1.3).

\subsubsection{The example of the ACWL}

To date, the only advisory centre at the international level is the ACWL. Even if this example cannot be fully transposed to investment arbitration given the differences that may exist between the WTO dispute settlement system and ISDS, there are some lessons to be drawn from the example of the ACWL. During its first ten years of existence, the ACWL has been

\footnotetext{
12 Joubin-Bret (2015), pp. 4-7.

${ }^{13}$ Alisher (2016), pp. 1-3.

14 ACWL, Report on $\quad$ Operations 2018 , https://www.acwl.ch/download/dd/reports_ops/Final_Report_on_Operations_2018-for-website.pdf (last accessed 14 January 2020), pp. 14, 47.

${ }^{15}$ Alisher (2016), p. 2; Joubin-Bret (2015), p. 9.

${ }^{16}$ UNCITRAL Working Group III (Investor-State Dispute Settlement Reform), Possible Reforms of Investor-State dispute settlement, Submission from the Government of Thailand, 8 March 2019, https://undocs.org/en/A/CN.9/WG.III/WP.162 (last accessed 14 January 2020), p. 5.
} 
involved in almost $20 \%$ of cases settled at the WTO, that is, in more than 35 cases. ${ }^{17}$ "If the ACWL itself were a WTO member country, it would be the third most frequent litigant during the period trailing only the US and EU and ahead of China." 18 This means that in the $80 \%$ other cases, litigant states have relied mainly on governmental legal expertise or legal advisers from the WTO Secretariat ${ }^{19}$ but also on law firms specialized in international trade law. ${ }^{20}$ The fact that only developing and least developed countries (a total of 79 countries) are entitled to have recourse to such the ACWL may also explain this small portion. When the ACWL, i.e. because of a conflict of interest, cannot provide services to a litigant state, it has established, since 2015, a roster of external counsel. This roster, essentially composed of law firms, can intervene in the context of a specific dispute but also for provide general legal advice. ${ }^{21}$

\subsubsection{The workload in ISDS is too heavy to be exclusively handled by an ACIL}

If the ACWL has been involved in almost $20 \%$ of WTO cases, is it possible for an ACIL to have a bigger portion of cases in the field of ISDS? We would say no given the fact that investment cases are longer, more costly and more important in number in comparison to WTO cases. To date, are known more than 1000 ISDS cases and this number keeps growing at a rapid pace. In addition, the average length of investment treaty arbitration is between 3 and 5 years ${ }^{22}$ while, according to the WTO DSU time frames, dispute settlement at the WTO is supposed to take 308.5 days until the circulation of the Panel Report and a maximum of 458.5 days until the Appellate Body Report. ${ }^{23}$

\footnotetext{
${ }^{17}$ Joubin-Bret (2015), p. 9; Schwieder (2018a), p. 634.

${ }^{18}$ Brown and Reynolds (2015) pp. 160.

${ }^{19}$ Article 27 al. 2 of Dispute Settlement Understanding (DSU) on rules and procedures governing the settlement of disputes (Annex 2 of the WTO Agreement).

${ }^{20}$ It should be recalled that the admission of private lawyers on governmental delegations before WTO DSB in now an established principle, see WTO, Panel Report, European Communities - Regime for the Importation, Sale and Distribution of Bananas, 22 May 1997, WT/DS27/R/GTM; WTO, Appellate Body Report, European Communities - Bananas, 09 September 1997, WT/DS27/AB/R; WTO, Panel Report, Indonesia - Certain Measures Affecting the Automobile Industry, 02 July 1998, WT/DS54/R WT/DS55/R WT/DS59/R WT/DS64/R; WTO, Panel Report, Korea - Taxes on Alcoholic Beverages, 17 September 1998, WT/DS75/R WT/DS84/R Risep. This principle is less established in the context of consultations that precede the establishment of a panel, see Statements by the United States at the Meeting of the WTO Dispute Settlement Body Geneva, November 21, 2018, pp. 4042 , to be found at: https://geneva.usmission.gov/wp-content/uploads/sites/290/Nov21.DSB_.Stmt_asdeliv.fin_.public.pdf (last accessed 14 January 2020).

21 https://www.acwl.ch/download/dd/reports_ops/Final_Report_on_Operations_2018-for-website.pdf (last accessed 14 January 2020).

${ }^{22}$ Many recent studies have investigated the issue of ISDS length: Franck establishes the average length at 3.5 years, see Franck (2019) pp. 122. 124, 126; other authors found that the average length of investment arbitration is 3.73, see Langford, Behn and Létourneau-Tremblay (2019), p. 16.

${ }^{23}$ In practice, cases vary a lot in length from less than one year (see US-Wool Shirts and Blouses) to more than six years Australia- Tobacco Plain Packaging (Indonesia). But it is safe to say that ISDS cases are, on average, longer than WTO cases.
} 
ISDS is also costly: where a typical WTO case costs, on average, about US $\$ 600,000$ to 700,000 an investment arbitration costs more than US $\$ 4$ million. ${ }^{24}$ This is equivalent to the ACWL annual budget, which is rising to CHF4.665 million for $2019 .{ }^{25}$ In our opinion, it will be difficult for a small, permanent institution to be involved in long and costly ISDS cases. Such a centre cannot be entrusted with the management of all ISDS cases. This is particularly true if such an ACIL is supposed to provide services not only to developing countries but also to SMEs as contemplated (at least at this stage still) in the UNCITRAL provisional agenda.

\subsubsection{ACIL and counsel fees}

As already Napoleon Bonaparte said, money is the sinews of war. If the apparent opposition of counsel to the establishment of an ACIL is due to the fear of experiencing a significant lowering of their fees, we think this is not very likely. Will the establishment of an ACIL have any impact on counsel fees? Because of the lack of transparency in the costs assumed by litigant states before the WTO, it is difficult to deepen the analysis as to whether the ACWL has had an impact on legal fees at the WTO. However, it is unlikely that the existence of this centre will 'directly' reduce the fees of counsel. As a reminder, these fees are freely fixed. States may have recourse to a restricted or general tender for the recruitment of external counsel. ${ }^{26}$ Besides, they may hire counsel on a claim-by-claim basis ${ }^{27}$ or have a continuing retainer with one firm ${ }^{28}$. Nevertheless, the ACIL may 'indirectly' have an impact on counsel fees by reducing the "time, counsel spend

\footnotetext{
${ }^{24}$ Franck (2019), pp. 113-140; Langford, Behn and Létourneau-Tremblay (2019), pp. 7-8.

${ }^{25}$ ACWL, Budget for 2019, Proposal of the Management Board, ACWL/MB/W/2018/6, 05 October 2018, https://www.acwl.ch/download/general_assembly mmeting_documents/11.12.2018/ACWL-MB-W-2018-6Budget-for-2019.pdf (last accessed 14 January 2020).

26 "Documents published on the website of Costa Rica's ministry of finance shed light on how the state chooses external counsel. For each tender, the ministry of foreign trade drew up a list of seven or eight vetted international firms, tallying their successes and failures in other treaty cases on behalf of states and investors. It also supplied an estimate of the value of the contract. Recommended firms were invited to make bids - but the list differed for each case... Only four firms put in bids. Allen \& Overy's was the highest, at just under US $\$ 2.37$ million, followed by Baker Botts at US $\$ 1.75$ million. Two firms came in below the ministry's target - White \& Case bidding US\$1.57 million and Sidley making the winning bid of just under US\$1.15 million”, see Parry (2013)

27 " Arrangements for the defence of Ukraine in investment arbitration are determined by the Ministry of Justice of Ukraine on a claim-by-claim basis. Services of internal and/or external counsel may be used for these purposes. The Law of Ukraine "On Public Procurements" No. 922-VIII dated 25 December 2015, which entered into force on 1 April 2016, regulates the public procurement of legal services connected with the representation of Ukraine in international juridical bodies. In particular, the Law stipulates that such services may be procured in accordance with special negotiation procedure (i.e., after negotiations with one or several participants) under the decision of the Cabinet of Ministers of Ukraine or the National Security and Defence Council of Ukraine - or through the two-stage competitive dialogue procedure. General procurement process may also apply" see Droug and Gontar (2018), p.12.

${ }^{28}$ Société Générale de surveillance SA v. Pakistan, ICSID Case No. ARB/01/13, Decision on disqualification of Arbitrator, 19 December 2002, ICSID Reports, Volume 8, p. 398.
} 
by working on a case. There is a link between cost and duration and if the time spent on a case is reduced, this might probably impact fees counsel charge to litigant states. A recent study shows that longer times to resolve disputes were associated with higher legal costs, and cases resolved more quickly had lower legal costs for state." 29

ACIL may help in that sense since one of its goals is to build the expertise of states' agents in international investment law and in handling ISDS procedures. Reaching this goal may also help in reducing the amount of counsel's work and, consequently, their fees:

"a standing agent can help control costs through better allocation of government personnel and resources. Counsel fees generally constitute the bulk of arbitration costs. State lawyers invariably cost less than experienced outside counsel. Much arbitration work can be performed even within those governments that lack significant experience in international investment arbitration. Government lawyers, for instance, may retrieve and review documents; identify and interview potential witnesses; prepare timelines and memoranda on key issues; and research local law. Performing such time-consuming work internally can substantially reduce the State's litigation costs." 30

\subsection{ACIL and counsel's mission of state assistance}

This section will start with some remarks on legal representation and assistance in the context of international litigation (2.2.1). Then the problems raised by the use of counsel (and other private lawyers) as representatives of litigant states will be examined (2.2.2) as well as the benefits counsel may gain from the establishment of an ACIL (2.2.3).

\subsubsection{Representation and assistance before international courts and tribunals}

In international litigation, there are two major aspects in the representation of litigant states: the representation (properly speaking) and the assistance as e.g. emphasized in the Article 42 of the International Court of Justice (ICJ) Statute. ${ }^{31}$ In the context of investment arbitration, Rule 18 al. 1 of ICSID Arbitration Rules provides: “(1) Each party may be represented or assisted by

\footnotetext{
${ }^{29}$ Franck (2019), p. 136.

${ }^{30}$ Sharpe (2018), p. 693.

${ }^{31}$ Statute of the International Court of Justice, adopted the 26 June 1945, entered into force 24 October 1945; see also Article 53 ITLOS Rules of the Tribunal, as adopted on 28 October 1997 and amended on 15 March 2001,21 September 2001, 17 March 2009 and 25 September 2018.
} 
agents, counsel or advocates whose names and authority shall be notified by that party to the Secretary-General, who shall promptly inform the Tribunal and the other party."32

The representative (also called agent) is vested with "full power to bind the government and to take all the decisions necessary in the course of the proceedings" while the assistant does not possess such an authority. ${ }^{33}$ Actually, the agent's functions have diplomatic and political implications that go beyond the legal aspects in the settlement of a dispute. ${ }^{34}$ That is why some states have a special department devoted to the defence of their interests in international adjudication. Empirically, states' agents have generally been designated among civil servants and political figureheads. ${ }^{35}$ However, many countries do not possess the required expertise at the national level and tend to outsource their representation before international courts to international law firms. ${ }^{36}$ This is also due to the fact that texts governing proceedings before international courts and tribunals are normally silent on the identity of persons, litigant states may appoint as agents or counsel. The appointment of lawyers, operating in private practice as agents, has been criticized before international courts and tribunals and some of this criticism will be examined in the following section. ${ }^{37}$

\subsubsection{Problems arising regarding the appointment of (external) counsel}

First, the appointment of a counsel as a state agent raises issues of representativeness. By representativeness, we mean the fact to be perceived as a legitimate representative of a litigant states. E.g. in the Norstar case before the International Tribunal for the Law of the Sea (ITLOS), a lawyer, operating in private practice, represented Panama as agent. However, this choice was questioned by Italy on the grounds that such agent "was not vested with powers to negotiate with Italy over the facts of the present case." ${ }^{38}$ Italy pretended that this lawyer missed

\footnotetext{
${ }^{32}$ Rule 18 of ICSID Arbitration Rules; see also Article 5 of UNCITRAL Arbitration Rules adopted in 2013.

${ }^{33}$ Rosenne (2006), p.1133.

${ }^{34}$ Matheson (2002), pp. 467-479; see also Rosenne (1993), pp. 41-68.

${ }^{35}$ In comparison, non-state litigants are represented by counsel and advocates, see Article 19 CJEU Statute.

36 "States have traditionally adopted three different approaches to the defence of their interests in ISDS cases. Some States organize their defence through a dedicated in-house team. Other States use a combination of an inhouse team working in various degrees of cooperation with outside counsel. The vast majority of States outsource their defence to outside counsel”, UNCITRAL Working Group III (Investor-State Dispute Settlement Reform), Possible Reform of Investor-State Dispute Settlement (ISDS) Advisory Centre, Note by the Secretariat, https://undocs.org/en/A/CN.9/WG.III/WP.168 (last accessed 16 January 2020), p. 3.

${ }^{37}$ See Cot (2002), p. 835, Ziegler and Kabre (2019), pp. 544-565; see also M/V "Louisa" (Saint Vincent and the Grenadines v. Kingdom of Spain), Judgment, Separate Opinion of Judge Cot, ITLOS Reports 2013, p. 114, https://www.itlos.org/fileadmin/itlos/documents/cases/case no_18_merits/published/C18_Cot_280513.pdf (last accessed 16 January 2020).

${ }^{38}$ See M/V "Norstar" (Panama v. Italy), Preliminary Objections, Judgment, ITLOS Reports 2016, p. 19, para. 66
} 
representative powers and authority to act on behalf of Panama while, and according to the latter country, "the Rules of the Tribunal do not prohibit a party being represented by a "private lawyer." Finally, and according to the Tribunal, "the fact that Mr Carreyó is a lawyer in private practice, acting as a legal representative of the owner of the M/V "Norstar", does not imply that Panama is prevented from entrusting him with the powers to represent Panama." 39 However, the Tribunal added that "for communications sent by a lawyer in private practice on behalf of a State to be opposable to another State, the latter needs to be duly informed of the authority conferred on the lawyer to represent the former State. Therefore, the mere reference in a letter by a private person to the authorization given to that person by the State may not be sufficient." ${ }^{40}$ Such an appointment has been described as "unusual" by some members of the Tribunal notably Judge $\operatorname{Cot}^{41}$ and Judge Anderson. ${ }^{42}$ The latter explained that a private lawyer is not "well placed" to provide information to the Tribunal. ${ }^{43}$ Maybe, it is worth recalling also the statement of Judge Oda in which he criticised the representative of one litigant state for not being a person holding high office in the represented Government, but rather being a "private lawyer.',44

The second problem is related to the reliability of private counsel. As the link between the tribunal and the represented state, the agent is expected to have high reliability and this requires not only legal expertise but also good knowledge of local realities. When the representative is a private lawyer (most of the time from another country), this reliability may be questionable. In the Grand Prince case (Belize v. France) before ITLOS, the agent appointed by Belize either

https://www.itlos.org/fileadmin/itlos/documents/cases/case no.25/Preliminary_Objections/Judgment/C25 Judg ment 04.11.16 orig.pdf (last accessed 16 January 2020).

${ }^{39} \mathrm{M} / \mathrm{V}$ "Norstar" (Panama v. Italy), Preliminary Objections, Judgment, ITLOS Reports 2016, p. 25, para. 95, https://www.itlos.org/fileadmin/itlos/documents/cases/case_no.25/Preliminary_Objections/Judgment/C25 Judg ment_04.11.16_orig.pdf (last accessed 16 January 2020).

${ }^{40} \mathrm{M} / \mathrm{V}$ “Norstar” (Panama v. Italy), Preliminary Objections, Judgment, ITLOS Reports 2016, p. 25, para. 94, https://www.itlos.org/fileadmin/itlos/documents/cases/case_no.25/Preliminary_Objections/Judgment/C25 Judg ment_04.11.16 orig.pdf (last accessed 16 January 2020).

${ }^{41}$ See M/V 'Norstar' (Panama v. Italy), Preliminary Objections, Judgement, Declaration of Judge Cot, ITLOS Reports 2016, p.

https://www.itlos.org/fileadmin/itlos/documents/cases/case_no.25/Preliminary_Objections/Judgment/C25_J_041 116_decl_Cot_TR.pdf (last accessed 16 January 2020).

42 'Grand Prince' Case (Belize v. France), Prompt Release, Judgment, Separate Opinion of Judge Anderson, 20 April 2001, p. 54, https://www.itlos.org/fileadmin/itlos/documents/cases/case_no_8/published/C8-J-20_apr_01SO_A.pdf (last accessed 16 January 2020).

43 'Grand Prince' Case (Belize v. France), Prompt Release, Judgment, Separate Opinion of Judge Anderson, 20 April 2001, p. 54, https://www.itlos.org/fileadmin/itlos/documents/cases/case no 8/published/C8-J-20_apr_01SO_A.pdf (last accessed 16 January 2020).

${ }^{44}$ Armed activities on the territory of the Congo (Democratic Republic of the Congo v. Uganda), Provisional Measures, Order of 1 July 2000, I.C.J. Reports 2000, Declaration of Judge Oda, at 132. 
was unable to provide the tribunal with information ${ }^{45}$ or provided "incomplete and contradictory information." 46 In another case, it seems that the information provided by the counsel, appearing as state agent, were not in line with "the view of the law as it emerges from the decision of the Regional Court of Bissau.',47

The third problem is related to the lack of accountability mechanisms for counsel before international courts and tribunals. This was underlined again by the Judge Cot is his opinion in the Louisa case before ITLOS. ${ }^{48}$ In this case, the private lawyer appointed as agent by Saint Vincent and the Grenadines used "guerrilla tactics" (notably with the belated production of an important piece of evidence and lies) and tried to mislead the tribunal. However, his behaviours remained unpunished. The Tribunal expressed only regrets. ${ }^{49}$ For Judge Cot, litigant states, "acting in sovereign fashion, organize their representation and the defence of their interests. They do so at their own risk. ${ }^{50}$ We think that the risk is also for the international tribunals and for the international community as a whole, given the consequences a decision tainted with an error may have in the development of international law. The attribution of agents' conducts to the represented state is a major principle of international law. ${ }^{51}$ However, and contrary to government agents, private lawyers are not de facto subordinate to the sovereign authority of litigant states and this lack of accountability mechanisms may lead to an "ethical no man's land"' and also be seen as a charge of illegitimacy often voiced against counsel.

\footnotetext{
45 'Grand Prince' Case (Belize v. France), Prompt Release, Judgment, Separate Opinion of Judge Anderson, 20 April 2001, p. 54, https://www.itlos.org/fileadmin/itlos/documents/cases/case_no_8/published/C8-J-20_apr_01SO_A.pdf (last accessed 16 January 2020).

46 'Grand Prince' Case (Belize v. France), Prompt Release, Judgment, , Declaration of Judge ad hoc Cot, p. 53, para. 14, https://www.itlos.org/fileadmin/itlos/documents/cases/case_no_8/published/C8-J-20_apr_01-D_C.pdf (last accessed 16 January 2020).

47 "Juno Trader" (Saint Vincent and the Grenadines v. Guinea-Bissau), Prompt Release, Judgment, Joint Separate Opinion of Judges Mensah and Wolfrum, ITLOS Reports 2004, p. 59, para. 6, https://www.itlos.org/fileadmin/itlos/documents/cases/case_no_13/13_judgment_181204_sep_op_Wolfrum_Me nsah_en.pdf (last accessed 16 January 2020). [is:pe?

${ }^{48} \mathrm{M} / \mathrm{V}$ "Louisa" (Saint Vincent and the Grenadines v. Kingdom of Spain), Judgment, Separate Opinion of Judge Cot, ITLOS Reports $\quad 2013, \quad$ p. 114 , https://www.itlos.org/fileadmin/itlos/documents/cases/case_no_18 merits/published/C18_Cot_280513.pdf (last

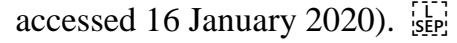

${ }^{49} \mathrm{M} / \mathrm{V}$ "Louisa" (Saint Vincent and the Grenadines v. Kingdom of Spain), Judgment, ITLOS Reports 2013, p. 24, para.

https://www.itlos.org/fileadmin/itlos/documents/cases/case_no_18_merits/published/C18_Judgment_280513.pdf (last accessed 16 January 2020).

50 'Grand Prince' Case (Belize v. France), Prompt Release, Judgment, Declaration of Judge ad hoc Cot, p. 53, para. 15, https://www.itlos.org/fileadmin/itlos/documents/cases/case_no_8/published/C8-J-20_apr_01-D_C.pdf (last accessed 16 January 2020).

${ }^{51}$ See, for example the Articles 4 to 6 of the International Law Commission, Responsibility for States for Internationally 
The various types of criticism described have been made in the context of inter-state dispute resolution (especially before ITLOS). What about in the ISDS context? Before arbitral investment tribunals, even if some counsel have appeared as states' representatives, some authors consider that counsel cannot play the role of agent. For one author "the absence of a government agent may fatally undermines the state's case." ${ }^{52}$ However, we think that the lack of experience of government agents may also undermine a state's case. In the CDC Group case (ICSID), for example, the Republic of Seychelles' officials (appearing as agents) have demonstrated their incompetence to defend their state's interests, notably with a countermemorial incorrectly drafted and poor management of witnesses. ${ }^{53}$

Before arbitral investment tribunals, the major reproach to counsel, assuming the functions of state representative, is to be found at the level of the pleadings by a State. Because of the dual role of states in ISDS ${ }^{54}$, many investment tribunals tend to not consider pleadings and statements made by counsel as truly reflecting the position of the represented states. For example, in Urbaser SA and Consorcio de Aguas Bilbao Bizkaia, Bilbao Biskaia Ur Partzuergoa $v$ Argentine Republic, the tribunal found that the argumentation made by the counsel of the Kingdom of Spain in the Maffezini case "does not allow a broader understanding concerning an interpretation shared by the Spanish Government in general pertaining to the application of certain provisions of the BIT." 55 Some authors also think that arguments made by counsel do not necessarily reflect the official position of the state concerned "where a law firm hired to fend off a claim represents the state, it is even less obvious that a particular argument corresponds to the state's genuine position." ${ }^{, 56}$ Another reproach is the lack of ethical

\footnotetext{
${ }^{52}$ Sharpe (2018), p. 680.

${ }^{53}$ See CDC Group PLC v. Seychelles, ICSID Case No. ARB/02/14, Award, 17 December 2003, p. 8, http://icsidfiles.worldbank.org/icsid/ICSIDBLOBS/OnlineAwards/C219/DC696_En.pdf (last accessed 14 January 2020).

${ }^{54}$ Magraw (2015), pp. 142-171; Roberts (2010), p. 179.

${ }^{55}$ Urbaser SA and Consorcio de Aguas Bilbao Bizkaia, Bilbao Biskaia Ur Partzuergoa v. Argentine, ICSID Case No. ARB/07/26, Decision on Jurisdiction, 19 December 2012, p. 14, para. 51, https://www.italaw.com/sites/default/files/case-documents/italaw1324.pdf (last accessed 14 January 2020). See also Sempra Energy International v. Argentine, ICSID Case No. ARB/02/16, Decision on Objections to $\begin{array}{llllll}\text { Jurisdiction, } & 11 \text { May } & \text { 2005, } & \text { p. } & \text { para. } & 146 \text {, }\end{array}$ http://icsidfiles.worldbank.org/icsid/ICSIDBLOBS/OnlineAwards/C8/DC509_En.pdf (last accessed 14 January 2020); Enron Corporation and Ponderosa Assets, L.P. v. Argentine, ICSID Case No. ARB/01/3, Decision on Jurisdiction (Ancillary Claim), 02 August 2004, p. 12, para. 39, http://icsidfiles.worldbank.org/icsid/ICSIDBLOBS/OnlineAwards/C3/DC502_En.pdf (last accessed 14 January 2020).

56 Schreuer (2016), p. 737.
} 
rules for counsel in investment arbitration but things are changing (as we will see further below).

\subsubsection{Some benefits counsel may gain from the establishment of an ACIL}

Against this background of reproaches and criticisms, the establishment of an ACIL may help in a better distribution of roles between government agents and external counsel. We think that the proper management of a case requires coordination between local authorities and external counsel and that the full outsourcing of state representation is normally not a viable option. In addition, and when counsels assume their traditional role of state's assistance, their action is most of the time praised as evidenced in the Yukos case where counsels of both parties were commended for "their high professionalism." 57

In addition, the ACIL will help in building governmental expertise in managing ISDS cases and, consequently, allowing the appointment of governmental agents. Such an appointment may help external counsel to know where to go when they need specific information or whom to contact. This may result in a gain of time and a better coordination between all the actors involved in the representation of the litigant states.

\section{Counsel under the Comprehensive Economic and Trade Agreement}

Independence and impartiality are the heart of any judiciary system and they are mentioned in almost all the texts creating international courts and tribunals. ${ }^{58}$ In the context of ISDS, the independence and impartiality of arbitrators have been a major concern. Some of them have been accused of lacking independence and impartiality notably when assuming others' roles or being engaged in inappropriate contacts with litigant parties. Being aware of this, many states and regional organizations have included in their recent agreements, rules of ethics and codes of conduct for arbitrators. This is particularly true for the EU and this idea has been included in

\footnotetext{
${ }^{57}$ PCA case No. AA 227, Yukos Universal Limited (Isle of Man) vs. The Russian Federation, Final award, 18 July 2014, p. 577, para. 1880, https://www.italaw.com/sites/default/files/case-documents/italaw3279.pdf (last accessed 14 January 2020).

${ }^{58}$ See, for example, Articles 2 and 20 ICJ Statute, Article 6 Convention for the Protection of Human Rights and Fundamental Freedoms of the 04 November 1950, Article 40 Rome Statute of the International Criminal Court.
} 
the UNCITRAL reform proposals. ${ }^{59}$ These recent solutions regarding arbitrators may be applicable also to counsel in, at least, two situations: (1) When the arbitrator, in one case, is also counsel in another case: the double-hat syndrome. (2) When a counsel and an arbitrator come from the same law firm or have other personal or professional links. ${ }^{60}$ The example of the CETA, concluded between the EU and the Canada and entered into force provisionally on 21 September 2017, will help us identifying rules and their possible application to counsel.

3.1 CETA and the regulation of the double-hat syndrome

According to article 8.30 CETA entitled "Ethics":

"[t]he Members of the Tribunal shall be independent. They shall not be affiliated with any government. They shall not take instructions from any organisation, or government with regard to matters related to the dispute. They shall not participate in the consideration of any disputes that would create a direct or indirect conflict of interest. They shall comply with the International Bar Association Guidelines on Conflicts of Interest in International Arbitration or any supplemental rules adopted pursuant to Article 8.44.2. In addition, upon appointment, they shall refrain from acting as counsel or as party-appointed expert or witness in any pending or new investment dispute under this or any other international agreement (emphasis added)."

This provision deals with one of the ISDS' major problems: the double hat phenomenon or dilemma. ${ }^{61}$ Some authors have empirically measured this phenomenon and found that "a total of $47 \%$ of cases (509 in total) involve at least one arbitrator simultaneously acting as legal counsel." ${ }^{62}$ Even if a lot has been said on the double-hatting, it is still unclear whether there is a problem of principle for someone to assume two roles (mainly the roles of arbitrator and counsel but also arbitrator and expert or secretary of the tribunal). Nevertheless, at least for an external observer, this confusion of role may seem inappropriate. According to UNCITRAL Working Group III, “the practice posed a number of issues including potential and actual conflict of interest. It was stated that even the appearance of impropriety (for example,

\footnotetext{
${ }^{59}$ UNCITRAL, Report of Working Group III (Investor-State Dispute Settlement Reform) on the work of its thirtyseventh session (New York, 1-5 April 2019), https://undocs.org/en/A/CN.9/970 (last accessed 14 January 2020), p. 15, para. 84; see also Giorgetti and Wahab (2018), pp. 1-13.

${ }^{60}$ Pérez (2018), pp.105-128.

${ }^{61}$ See Fach Gómez K (2019), pp. 102-115.

${ }^{62}$ Langford, Behn and Lie (2017), p. 6.
} 
suspicion that arbitrators would decide in a manner so as to benefit a party it represented in another dispute) had a negative impact on the perception of legitimacy of ISDS."

The relationship between arbitrator and counsel represents the majority of conflicts of interest challenges in ISDS. ${ }^{64}$ The same person can assume the two functions, either simultaneously (the double-hat phenomenon) or successively; counsel and arbitrators can have professional or personal relationships, notably when they come from the same firm.

The solutions found in Article 8:30 CETA have three important consequences: First, this CETA provision expressly prohibits double-hatting by establishing a clear barrier between arbitrators and counsel. This is in line with the ICJ Statute that also establishes incompatibilities between the bench and the bar. ${ }^{65}$ Even more, the ICJ decided last year that its judges would not participate in ISDS proceedings as arbitrators. ${ }^{66}$ The fact that CETA establishes a permanent court may explain why it has adopted the practice followed by other permanent courts such as the ICJ or ITLOS. However, the possibility to transpose such a rule to ad hoc investment tribunals (in the case of ICSID or UNCITRAL for example) may be questionable or at least difficult.

Secondly, the CETA provides a legally binding character to an important (but otherwise soft law) text, the International Bar Association Guidelines on Conflicts of Interest in International Arbitration, as adopted on 23 October 2014 and updated on 10 August 2015. This text was already applicable in ISDS arbitration proceedings but only with prior agreement of litigant parties. Now, such prior agreement is no longer required under CETA. Also, some tribunals have had recourse to it for assessing challenges to arbitrators' independence and impartiality (where the text was not legally applicable as such). These Guidelines contain two parts: Part I deals with "General Standards Regarding Impartiality, Independence and Disclosure" while Part II focuses on the "Practical Application of the General Standards". Some general standards are of particular importance for counsel notably General Standards 6 and 7. The former relates

\footnotetext{
${ }^{63}$ UNCITRAL, Report of Working Group III (Investor-State Dispute Settlement Reform) on the work of its thirtyfifth session (New York, 23-27 April 2018), https://undocs.org/en/A/CN.9/935 (last accessed 14 January 2020), p. 12, para. 78. Bernasconi-Osterwalder, Johnson and Marshall (2010), p.17.

${ }^{64}$ Kinnear and Nitschke (2015), p. 53.

${ }^{65}$ Article 17 ICJ Statute; see also Article ITLOS Statute.

${ }^{66}$ Speech by H.E. Mr Abdulqawi A. Yusuf, President of the International Court of Justice, on the occasion of the seventy-third session of the United Nations General Assembly, 25 October 2018, https://www.icjcij.org/files/press-releases/0/000-20181025-PRE-02-00-EN.pdf (last accessed 14 January 2020), pp. 11-12.
} 
to the relationship between arbitrator and their law firms, litigant parties and other parties and the latter is about the duties of the parties and the arbitrator. Of one the most innovative aspects of these Guidelines is the different lists (red, orange, green) it provides to deal with the different conflicts of interests that may appear in the course of the dispute settlement (traffic-light approach).

Thirdly, this provision opens the door to the application of other rules "adopted pursuant to Article 8.44.2', The state: "Paragraph 1 [of Article 8.44] shall not exclude the possibility of dispute settlement under Chapter Twenty-Nine (Dispute Settlement) in respect of a measure of general application even if that measure is alleged to have breached this Agreement as regards a specific investment in respect of which a claim has been submitted pursuant to Article 8.23 and is without prejudice to Article 8.38".

Does this mean that some other texts such as the IBA Rules on the Taking of Evidence in International Arbitration may receive a binding character in the future?

\subsection{A binding code of conduct for arbitrators (and counsel)?}

The CETA contains also its proper code of conduct for arbitrators and mediators (Annex 29B). However, the relevance of this code of conduct is limited by its lack of binding character. In fact, the code does not indicate what happens when an arbitrator does not comply with the provisions of the code. In case of arbitrator misconduct, the only option is to demand the replacement of the arbitrator according to Articles 22 and 23 of Rules of Procedure for Arbitration (Annex 29A).

Others recent agreements have also included a code of ethics for arbitrators such as the Singapore International Arbitration Centre (SIAC) Code of Ethics for an Arbitrator ${ }^{67}$ or the Code of Conduct for Investor-State Dispute Settlement under Chapter 9 Section B of the Comprehensive and Progressive Agreement for Trans-Pacific Partnership. ${ }^{68}$ Such a code was also discussed at the $38^{\text {th }}$ meeting of the UNCITRAL Working Group III, on 14-18 October

\footnotetext{
${ }^{67} \mathrm{http} / / / \mathrm{www}$.siac.org.sg/our-rules/code-of-ethics-for-an-arbitrator (last accessed 14 January 2020).

68 Annex to CPTPP/COM/2019/D004, https://www.international.gc.ca/trade-commerce/trade-agreementsaccords-commerciaux/agr-acc/cptpp-ptpgp/isds code_conduct-rdei_code_conduite.aspx?lang=eng (last accessed 14 January 2020).
} 
2019 at Vienna. ${ }^{69}$ Recently, Chiara Giorgetti has been appointed as ICSID scholar in residence and her mandate includes, inter alia, the drafting of a Code of Conduct for Arbitrator. ${ }^{70}$

For a long time, investment arbitration has been described as an ethical no man's land mainly because of the absence of clear ethical rules for the actors involved in investment arbitration (arbitrators and counsel and others decisions-makers). The adoption of these Codes of Conduct is a step in direction of greater accountability of actors involved in ISDS. Many initiatives have proposed code of conduct for members of international courts and tribunals and also for counsel appearing before them. ${ }^{71}$

The idea of such a code is also in the table with regard to the negotiations at UNCITRAL with a possibility to extend it to counsel, according to the provisional agenda. We think that this organisation should adopt a bolder approach notably by including, in the discussions, the identity of the disciplinary body in charge of sanctioning counsel misconduct. In our opinion, arbitral tribunals already possess the 'inherent' powers to be entrusted with such a mission. What remains to be done is the formal consecration of such a power. In fact, international adjudicative bodies are reluctant to control and sanction counsel notably when the latter appears for a litigant state mainly for political (and not legal) reasons. One observer notes that:

"a public rebuke of counsel also says something distasteful about the State that hired (or employed) the lawyers and thus presumably instructed them on the case and provided the evidence to submit. Preferring to avoid the political costs, the Court may, if pressed to engage in public censure, become imbalanced in its discipline. It may, for instance, find itself more willing to censure private lawyers for misconduct than to censure government attorneys." 72

\footnotetext{
${ }^{69}$ UNCITRAL, Report of Working Group III (Investor-State Dispute Settlement Reform) on the work of its thirtyeighth session (Vienna, 14-18 October 2019), https://undocs.org/en/A/CN.9/1004 (last accessed 14 January 2020), pp. 11-15.

${ }_{70}$ ICSID News Release, Professor Chiara Giorgetti Joins ICSID as Scholar in Residence, 09 September 2019,https://icsid.worldbank.org/en/Pages/News.aspx?CID=340 (last accessed 14 January 2020).

${ }^{71}$ See, inter alia, The Hague Principles on Ethical Standards for Counsel Appearing Before International Courts and Tribunals, adopted the 27 September 2010 by the Study Group of the ILA on the Practice and Procedure of International Courts and Tribunals, https://www.ucl.ac.uk/international-courts/sites/internationalcourts/files/hague_sept2010.pdf (last accessed 14 January 2020) or the IBA Guidelines on Party Representation in International Arbitration, adopted the 25 May 2013, https://www.ibanet.org/Publications/publications_IBA_guides and free_materials.aspx (last accessed 14 January 2020).

${ }^{72}$ Skinner (2016), p. 297.
} 
This formal consecration already exists at the level of the EU where the Rules of Procedure allow the Court of Justice to exclude the representatives of litigant parties (including states representatives) in case of misconduct. In this regard, Article 46 states:

" 1 . If the Court considers that the conduct of an agent, adviser or lawyer before the Court is incompatible with the dignity of the Court or with the requirements of the proper administration of justice, or that such agent, adviser or lawyer is using his rights for purposes other than those for which they were granted, it shall inform the person concerned. If the Court informs the competent authorities to whom the person concerned is answerable, a copy of the letter sent to those authorities shall be forwarded to the person concerned. 2. On the same grounds, the Court may at any time, having heard the person concerned and the Advocate General, decide to exclude an agent, adviser or lawyer from the proceedings by reasoned order. That order shall have immediate effect." 73

UNCITRAL could also draw on experience from the International Criminal Court (ICC) where there are clear rules for the conduct of counsel notably with the code of professional conduct for counsel.

\section{Conclusion}

The different reforms of the ISDS will necessarily impact the role of counsel and this Chapter aimed at assessing this impact. Rather than a comprehensive analysis of ISDS reforms, our Chapter discussed two important amendments namely the establishment of an ACIL and the provisions of the CETA providing a code of conduct for arbitrators. In our opinion, counsel may benefit from the setting up of an ACIL notably because the latter will help counsel to refocus on assisting litigant states and not representing them. Admittedly, this advisory centre may provide legal services to litigant parties in the same fashion counsels do. But, especially given the number and the length of investment disputes, such a centre cannot be entrusted with the exclusive management of all those disputes. Rather, we advocate in favour of complementary between them as it has occurred at the level of WTO with the ACWL and the roster of counsels.

\footnotetext{
${ }^{73}$ Rules of Procedure of the Court of Justice of 25 September 2012 (OJ L 265, 29.9.2012), as amended on 18 June 2013 (OJ L 173, 26.6.2013, p. 65), on 19 July 2016 (OJ L 217, 12.8.2016, p. 69) and on 9 April 2019 (OJ L 111, 25.4.2019, p. 73).
} 
From the other hand, the CETA tackled the problem of double-hatting and also adopted a code of conduct for arbitrators. Given the relationship between arbitrators and counsel, these provisions may be analysed as an indirect regulation of the role of the counsel. We think that international organisations should adopt a bolder approach with a direct regulation of counsel. In that way, the UNCITRAL Working Group may include, in its next rounds of discussions, the topic related to the identity of the disciplinary body in charge of sanctioning counsel misconduct. 


\section{REFERENCES}

Alisher U (2016) The case for an advisory center on international investment law. Columbia FDI Perspectives, No. 175 https://academiccommons.columbia.edu/doi/10.7916/D8445MNH Bernasconi-Osterwalder N, Johnson L, Marshall F (2010) Arbitrator independence and impartiality: examining the dual role of arbitrator and counsel. International Institute for Sustainable Development https://www.iisd.org/pdf/2011/dci_2010_arbitrator_independence.pdf

Brown C M (2017) A multilateral mechanism for the settlement of investment disputes, some preliminary sketches. ICSID Review, 32(3):673-690

Brown C, Reynolds K (2015) Trade flows and trade disputes. The Review of International Organizations. Springer, 10(2):145-177

Cot JP (2002) Appearing "for" or "on behalf of" a state: the role of private counsel before international tribunals. In: Nando et al. (eds) Liber Amicorum Judge Shigeru Oda, vol. II, Kluwer Law International, The Hague/London/New York, pp. 835-847

Droug O, Gontar O (2018) Ukraine. GAR Investment Treaty Arbitration, https://globalarbitrationreview.com/jurisdiction/1006275/ukraine

Fach Gómez K (2019) Key duties of international investment arbitrators. A transnational study of legal and ethical dilemmas. Springer, Switzerland

Franck S (2019) Arbitration Costs, myths and realities in international treaty arbitration. OUP, Oxford

Giorgetti C, Wahab M (2018) A code of conduct for arbitrators and judges, Academic Forum on ISDS Concept Paper 2019/12, 13 October 2019, https://www.jus.uio.no/pluricourts/english/projects/leginvest/academicforum/papers/papers/giorgetti-wahab-code-of-conduct-af-isds-paper-8-final--14-oct-2019$\underline{1 . p d f}$

Gottwald E (2007) Levelling the playing field: is it time for a legal assistance center for developing nations in investment treaty arbitration?. American University International Law Review 22:237-275

Joubin-Bret A (2015) Establishing an international advisory centre on investment disputes?. E15Initiative. Geneva: International Centre for Trade and Sustainable Development (ICTSD) and World Economic Forum, http://e15initiative.org/publications/establishing-aninternational-advisory-centre-on-investment-disputes 
Kinnear M, Nitschke F (2015) Disqualification of arbitrators under the ICSID Convention and Rules. In: Giorgetti C (ed) Challenges and recusals of judges and arbitrators in international courts and tribunals. Brill/Nijhoff, Leiden, pp. 34-79

Langford M, Behn D, Lie H (2017) The ethics and empirics of double hatting. ESIL Reflections $6(7): 1-12$

Langford M, Behn D, Létourneau-Tremblay L (2019) Empirical perspectives on investment arbitration: what do we know? Does it matter? ISDS Academic Forum Working Group 7 Paper, 15 March 2019, $\quad$ https://www.cids.ch/images/Documents/Academic-

Forum/7_Empirical_perspectives_-_WG7.pdf

Magraw K (2015) Investor-State disputes and the rise of recourse to state party pleadings as subsequent agreements or subsequent practice under the Vienna Convention on the Law of Treaties. ICSID Review 30(1):142-171

Matheson M J (2002) Practical aspects of the agent's role in cases before the international court. The Law and Practice of International Courts and Tribunals 1:467-479

Parry S (2013) Baker Botts and Sidley pick up Costa Rica cases, Global Arbitration Review, 26 July 2013, https://globalarbitrationreview.com/article/1032528/baker-botts-and-sidleypick-up-costa-rica-cases

Pérez A F (2018) Conflicts of interests of arbitrators in international law firms. Arbitration International 34(1):105-128

Roberts A (2010) Power and persuasion in investment treaty interpretation: the dual role of states. American Journal of International Law 104(2):179-225

Rosenne S (1993) The agent in litigation in the International Court of Justice. In: Kaplan W, McRae D (eds) Law, policy and international justice: essays in honour of Maxwell Cohen, McGill-Queen's University Press, Montreal/Kingston, pp. 41-68

Rosenne S (2006) The Law and the Practice of the International Court 1920-2005, 4è éd., vol. 3 procedure, Martinus Nijhoff Publishers, Leiden/Boston

Sauvant K P and Ortino F (2013) Improving the international investment law and policy regime: options for the future (Helsinki: Ministry for Foreign Affairs of Finland), http://ccsi.columbia.edu/files/2014/03/Improving-The-International-Investment-Law-and-

Policy-Regime-Options-for-the-Future-Sept-2013.pdf

Sauvant K P (2019) An advisory centre on international investment law: key features. Academic Forum on ISDS Concept Paper 2019/14, 10 September 2019, https://www.jus.uio.no/pluricourts/english/projects/leginvest/academicforum/papers/papers/sauvant-advisory-center-isds-af-14-2019.pdf 
Schreuer C (2016) The development of international law by ICSID tribunals. ICSID Review 31(3):728-739

Schwieder R W (2018) Legal aid and investment treaty disputes: lessons learned from the Advisory Centre on WTO law and investment experiences. The Journal of World Investment \& Trade 19(4):628-666

Schwieder R W (2018) Lessons for a future advisory center on international investment law.

Columbia FDI Perspectives, No. 241, http://ccsi.columbia.edu/files/2018/12/No-241-

$\underline{\text { Schwieder-FINAL.pdf }}$

Sharpe J (2018) The agent's indispensable role in international investment arbitration. ICSID Review 33(3):675-701

Sharpe J (2019) An international investment advisory center: beyond the WTO model. Published on July 26, 2019, available on https://www.ejiltalk.org/an-international-investmentadvisory-center-beyond-the-wto-model/

Skinner C P (2016) Ethical dilemmas in inter-State disputes. Alabama Law Review 68(1): 281301

Vidigal G, Stevens B (2018) Brazil's new model of dispute settlement for investment: return to the past or alternative for the future?. The Journal of World Investment \& Trade 19(3):475512

Ziegler A, Kabre J (2019) The legitimacy of private lawyers representing states before international tribunals. In: Baetens F (ed) Legitimacy of unseen actors in international adjudication. Cambridge University Press, Cambridge, pp. 544-565 


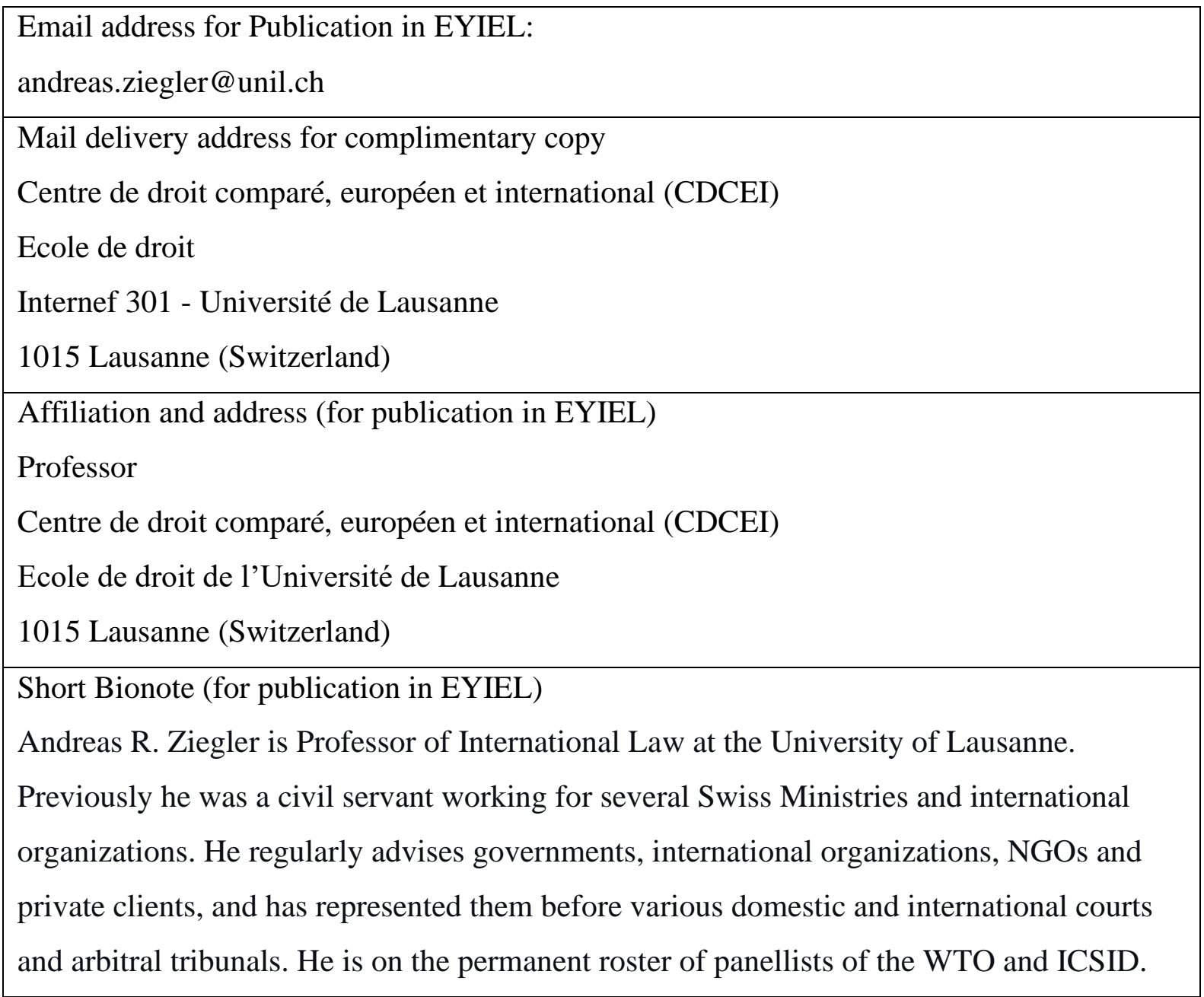

Email address for Publication in EYIEL:

rkabre@unil.ch

Mail delivery address for complimentary copy

Chemin de champ-pamont 101, 1033 Cheseaux-sur-Lausanne (Switzerland)

Affiliation and address (for publication in EYIEL)

Centre de droit comparé, européen et international (CDCEI)

Ecole de droit de l'Université de Lausanne

1015 Lausanne (Switzerland)

Short Bionote (for publication in EYIEL)

Jonathan R. Kabre studied law at University of Ouaga II (Burkina Faso) where he obtained LLB and LLM. He further obtained a Master of Law magna cum laude from the University of Lausanne (Switzerland) and recently defended his Ph.D. summa cum laude at the same 
University. As of February 2020, he will join the Centre of Human Rights of the University of Pretoria (South Africa) for conducting postdoctoral research in area of international development law and investment law. 